Vol. 7, Nomor 1, April 2013

\title{
Pendidikan Perempuan di Pondok Pesantren
}

\author{
Evi Muafiah \\ Sekolah Tinggi Agama Islam Negeri Ponorogo \\ Email: eviprogo@yahoo.co.id
}

\begin{abstract}
This article attempts to show women's education reality in pesantren, particularly pesantren that administers the two institutions at the same time, the education for men and for women. This is certainly different from those carry out the education specific for women. Indonesia has started to open educational opportunities for women at the time of R.A. Kartini, in which the previous women education was limited by the culture. The spirit to obtain education that equal with men was stated in her letters. Kartini had inspired some Indonesian women to get education as men. Later, some women who pioneered education for women appeared such as Rahmah el-Yunusiyah, Rangkayo Rasuna Said, Dewi Sartika etc. Each of them established a special school for girls with different studies taught.
\end{abstract}

Keywords: women education, pesantren, islamic boarding school

\begin{abstract}
Abstrak
Tulisan ini berupaya menunjukkan beberapa realitas pendidikan perempuan di pesantren, utamanya pesantren yang mengelola dua lembaga sekaligus, yaitu pendidikan untuk laki-laki dan pendidikan untuk perempuan. Hal ini tentunya berbeda dengan pendidikan yang dilakukan di lembaga pendidikan yang memang didirikan khusus untuk perempuan. Indonesia dapat dikatakan telah mulai membuka peluang pendidikan bagi perempuan pada masa RA Kartini, dimana sebelumnya pendidikan bagi perempuan sangat dibatasi oleh budaya yang terjadi saat itu. Semangat untuk memperoleh pendidikan yang setara dengan para laki-laki tertuang dalam surat-surat-nya. Kartini telah memberikan inspirasi bagi beberapa perempuan di Indonesia untuk mendapatkan pendidikan sebagaimana laki-laki. Hingga muncul pada masa-masa setelahnya beberapa perempuan yang mempelopori pendidikan bagi perempuan itu sendiri. Sebut saja misalnya: Rahmah el-Yunusiyah, Rangkayo Rasuna Said, Dewi Sartika dan lain sebagainya, dimana masing-masing dari mereka mendirikan sekolah khusus bagi perempuan dengan berbagai kajian yang berbeda yang diajarkan di sekolah tersebut.
\end{abstract}

Kata kunci: pendidikan wanita, pesantren 


\section{A. Pendahuluan}

Pembahasan tentang pentingnya pendidikan bagi perempuan di dunia modern ini telah dimulai sejak tahun 1970an, sejalan dengan lahirnya kritik kalangan feminis terhadap pembangunan yang merugikan perempuan. Padahal bisa jadi bahwa justru dengan melakukan pendidikan bagi perempuan akan dapat mengurangi dampak negatif dari pembangunan ekonomi karena pendidikan dapat meningkatkan akses perempuan terhadap pasar kerja dan memperbaiki keahlian mereka. Sehingga dengan demikian pendidikan sebenarnya mampu menjembatani permasalahan yang dihadapi perempuan dalam masa pembangunan. ${ }^{1}$

Seiring dengan perkembangan zaman, pendidikan perempuan akhirnya dirasa perlu, sehingga di beberapa daerah mulai berdiri lembaga pendidikan, termasuk di dalamnya pendirian lembaga pendidikan di lingkungan pesantren. Pendidikan bagi perempuan yang diselenggarakan di pesantren telah dimulai oleh Pondok Pesantren Mambaul Ma'arif Denanyar Jombang pada tahun 1921, dimana pesantren ini sebelumnya telah menyelenggarakan pendidikan bagi laki-laki. Pesantren ini awal mulanya menyediakan kelas yang tidak terpisah antara laki-laki dan perempuan, namun ketika jumlah santri sudah mungkin untuk dipisah maka selanjutnya pembelajaran dilaksanakan secara terpisah hingga saat ini. Apa yang dilakukan pesantren Denanyar ini juga diikuti oleh pesantren lain yang sebelumnya juga telah mempunyai santri lakilaki diawal pendirian masing-masing pesantren tersebut. ${ }^{2}$

Mayoritas pesantren pada awal pendiriannya didirikan khusus untuk putra, baru kemudian terpikirkan untuk mendirikan pesantren putri. ${ }^{3}$ Saat pertama mendirikan pesantren putri, kelas mereka biasanya belum terpisah antara laki-laki dan perempuan dengan

${ }^{1}$ Nurul Zakiyah, "Keterkaitan Pendidikan Formal Perempuan dan Dunia Pembangunan”, Jurnal Perempuan, Vol. 23, (Jakarta: Yayasan Jurnal Perempuan, 2002), hlm. 7.

${ }^{2}$ Misalnya Pesantren Salafiyah Syafi'iyah Situbondo, Pesantren Tambakberas Jombang, Pesantren Lirboyo Kediri, serta Pesantren Al-Munawir dan Ali Maksum Krapyak Yogyakarta.

${ }^{3}$ Hal ini terjadi pada Pondok Pesantren Mambaul Ma'arif Denanyar Jombang yang dikenal sebagai pesantren pertama yang mendirikan pesantren untuk putri pada tahun 1921 setelah berdiri sejak tahun 1917. Lihat Zamakhsyari Dhofier, Tradisi Pesantren, Studi Tentang Pandangan Hidup Kiai, (Jakarta: LP3ES, 1982), hlm. 39. 
alasan jumlah murid masih sedikit, namun ketika jumlah murid sudah meningkat, maka kelas tersebut mulai dipisah. Tradisi pemisahan kelas berdasarkan jenis kelamin ini diterapkan karena pesantren adalah sebuah lembaga yang memegang teguh karya-karya fiqh jaman pertengahan yang banyak mengharamkan pertemuan antara laki-laki dan perempuan di satu tempat bahkan mengharamkan munculnya perempuan di ranah publik. ${ }^{4}$ Jika harus berada di wilayah publik, maka harus dalam komunitas perempuan saja, dan jika laki-laki dan perempuan harus berada pada satu tempat, maka posisi harus dipisahkan dengan tirai pembatas atau biasanya lakilaki di depan dan perempuan di belakang. ${ }^{5}$ Tidaklah mengherankan apabila terdapat segregasi gender atau pemisahan antara lakilaki dan perempuan dalam pembelajaran di pesantren. Hal ini dapat dimaklumi karena pesantren adalah benteng bagi praktik Islam dan berkewajiban untuk memegang teguh ketentuan fiqh dan merealisasikan ke dalam kehidupan sehari-hari.

Tulisan ini berupaya menunjukkan beberapa realitas pendidikan perempuan di pesantren, utamanya pesantren yang mengelola dua lembaga sekaligus, yaitu pendidikan untuk laki-laki dan pendidikan untuk perempuan. Hal ini tentunya berbeda dengan pendidikan yang dilakukan di lembaga pendidikan yang memang didirikan khusus untuk perempuan. Pendidikan bagi perempuan yang dilakukan di pesantren, dimana pesantren tersebut juga menyediakan pendidikan bagi laki-laki dan dilaksanakan secara terpisah, tentunya mempunyai implikasi tersendiri bagi perempuan dalam hal pencapaian hasil belajar.

Tulisan ini akan diawali dengan pendidikan perempuan di masa Rasulullah Muhammad, dengan harapan akan mendapatkan gambaran tentang suasana pendidikan bagi perempuan pada masa tersebut, dilanjutkan dengan pemaparan tentang model pembela-

${ }^{4}$ Sebagaimana terdapat dalam kitab Is'aadurrofiiq Juz 2 halaman 27, kitab I'aanatutthoolibiin Juz 1 halaman 272 serta kitab 'Asyrotunnisaa' li an-nisaa' Juz 1 halaman 194, yang masing-masing menjelaskan tentang larangan ikhtilath atau bercampurnya laki-laki dan perempuan dalam satu tempat.

${ }^{5}$ Misalnya perempuan yang keluar rumah untuk mendatangi kegiatan agama dihukumi haram apabila berkeyakinan mendapat fitnah, sedangkan apabila tidak yakin tetapi menyangka akan muncul fitnah maka hukumnya haram dosa kecil. Lebih lanjut lihat Kholid Mawardi, "Madrasah Banat: Potret Pendidikan Anak Perempuan NU Masa Kolonial Belanda", Jurnal Studi Gender dan Anak Yin Yang, (Purwokerto: PSG STAIN Purwokerto, 2008), hlm. 239. 
jaran yang terpisah antara laki-laki dan perempuan dan yang dicampur dalam satu kelas, serta ditutup dengan realitas pembelajaran perempuan di beberapa pesantren yang secara garis besar terbagi menjadi dua, yaitu yang sudah sensitif gender dan yang masih bias gender.

\section{B. Pendidikan Perempuan di Masa Rasulullah}

Pendidikan Islam sudah terjadi sejak Nabi Muhammad diangkat menjadi Rasulullah di Mekah dan beliau sekaligus berperan sebagai guru. Pendidikan ini mulai dilakukan setelah beliau mendapatkan perintah dari Allah agar mendidik orang-orang yang ada di sekitarnya, mulai dari cara sembunyi-sembunyi hingga terang-terangan. Saat Islam sudah tersebar hingga Madinah, Rasulullah mulai membangun masjid untuk beribadah sekaligus tempat pembinaan muslim, termasuk sebagai tempat belajar.

Pada awal masa Islam tersebut, pendidikan bagi perempuan dilaksanakan di rumah anggota keluarga mereka sendiri dan dalam waktu tersendiri. Semisal Hafsah, sebelum dan sesudah menikah dengan Rasulullah, belajar di rumahnya sendiri. Hal ini karena budaya yang belum ramah bagi perempuan untuk keluar dari rumah sebagai usaha menuntut ilmu. Di dalam rumah akan lebih terhormat dan berwibawa, karena di luar rumah keamanan belum terjamin. Anak-anak perempuan hanya menerima pelajaran dari guru khusus yang datang ke rumahnya sendiri atau rumah kerabatnya. Bagaimanapun juga pendidikan secara pribadi ini telah berhasil melahirkan perempuan-perempuan Islam yang kecerdasannya tidak berbeda dengan kecerdasan laki-laki. ${ }^{6}$

Namun ada juga para perempuan yang tidak mau ketinggalan dengan laki-laki. Mereka meminta kepada Rasulullah waktu yang khusus sehari dalam seminggu, untuk belajar pada Rasulullah. Selain itu ada juga perempuan yang langsung menghadap Rasulullah untuk menanyakan permasalahan agama yang tidak mereka ketahui. $^{7}$ Akan tetapi pada masa berikutnya, mereka akhirnya belajar di luar rumah karena kondisi telah memungkinkan. Mereka sudah mulai mengikuti kegiatan pembelajaran yang diadakan oleh

6 Diantara perempuan-perempuan tersebut adalah Aisyah bint Abu Bakar, Hafsah bint Sirin, dan 'Amra bint Abdurrahman, lihat Ruth Roded, Kembang Peradaban, (Bandung: Mizan, 1995), hlm. 61-91.

${ }^{7}$ Mahmud Yunus, Sejarah Pendidikan Islam, (Jakarta: PT. Hidakarya Agung, 1990), hlm. 23. 
Rasulullah di masjid. Rasulullah menggunakan masjid untuk seluruh kegiatan beliau mulai dari pendidikan, latihan militer, diplomasi, tempat musyawarah dan lain sebagainya. Rasulullah menjadikan masjid sebagai lembaga pusat kehidupan bagi masyarakat tanpa membedakan laki-laki dan perempuan, bahkan beliau memberikan waktu khusus untuk mengajar perempuan. Perempuan pada masa Rasulullah seakan tidak mau ketinggalan dengan lakilaki, bahkan mereka mengikuti kegiatan shalat Jum'at dikarenakan ingin mendengarkan khutbah yang disampaikan Rasulullah. ${ }^{8}$

Namun kesempatan perempuan untuk mengikuti pembelajaran juga masih dibatasi oleh budaya sekitar, dalam arti tidak bebas begitu saja sebagaimana laki-laki, terutama setelah Rasulullah wafat. Banyak hasil pemikiran para tokoh pemikir perempuan yang tidak dimunculkan di wilayah publik, sehingga pada jaman setelahnya, banyak orang menganggap bahwa perempuan tidak layak untuk berpendidikan tinggi sebagaimana laki-laki. Pendidikan bagi perempuan masa klasik tidak banyak ditemukan sejarahnya, namun ada data yang menunjukkan bahwa perempuan telah ikut menghadiri suatu majelis yang terbuka. ${ }^{9}$ Mereka juga diberi kesempatan untuk bertanya. Dari paparan tersebut dapat dikatakan bahwa perempuan telah diberi kesempatan, utamanya kesempatan mengakses pendidikan, meskipun sangat terbatas dan hanya diakses oleh perempuan dalam jumlah yang sangat sedikit.

\section{Model Pembelajaran Bagi Perempuan}

Pesantren telah mengalami berbagai transformasi dimana diantaranya menggunakan prinsip almuhafazah ala qadimi aș-salih wal akhżu bil-jadidi as-aṣlah. Salah satunya adalah mengenai perkembangan santri yang belajar di pesantren. Pada mulanya pesantren hanya ditempati atau merupakan tempat belajar bagi laki-laki. Namun dengan adanya kebutuhan pendalaman pengetahuan dan ajaran agama, dan tentunya setelah melalui pertimbangan yang matang, akhirnya para kiai menerima santri perempuan.

Santri perempuan sebagai individu dan sekaligus makhluk sosial memerlukan komunitas sosial yang dapat menunjang kebu-

\footnotetext{
${ }^{8}$ Sebagaimana diceritakan dalam hadis Shahih Bukhari, CD Hadis asSyarif no. 6766.

${ }^{9}$ Hanun Asrohah, Sejarah Pendidikan Islam, (Jakarta: Logos, 2001), hlm. 97-98.
} 
tuhannya tentang pendidikan. Meskipun secara tradisi dikatakan bahwa perempuan adalah subjek kegiatan non moneter, seperti melahirkan, mengasuh serta mendidik anak dan melakukan pekerjaan domestik lainnya, namun perempuan tetap mempunyai peranan penting dalam keikutsertaannya menentukan kelancaran berbagai kegiatan dalam masyarakat. Perempuan dianggap sebagai makhluk yang dapat berperan ganda, baik di lingkungan keluarga sebagai ibu rumah tangga dan tenaga kerja, maupun pada lingkungan masyarakat sebagai bagian dari masyarakat itu sendiri, dimana mereka juga mempunyai hak serta kewajiban. Maka itulah pesantren membuka pendidikan untuk perempuan sebagai wahana belajar untuk bersimbiosis dengan masyarakat luas. ${ }^{10}$

Transformasi pendidikan di pesantren ini diharapkan membawa perubahan ke arah yang lebih baik dengan adanya peningkatan kualitas hidup melalui jalur pendidikan. Dengan berkembangnya ilmu pengetahuan dan teknologi yang semakin canggih, maka dapat memperbesar adanya suatu harapan untuk perubahan masyarakat. Santri perempuan sebagai muslimah mempunyai kewajiban untuk mengetahui dan mempelajari berbagai macam ilmu pengetahuan baik agama maupun non agama.

Di Indonesia terdapat beberapa macam sistem pendidikan pesantren yang mana masing-masing pesantren tersebut mempunyai sistem yang berbeda dalam melaksanakan pembelajaran, terutama bila dihubungkan dengan kebijakan pembelajaran bagi santri perempuan. Namun mayoritas pesantren menerapkan sistem pembelajaran yang terpisah antara santri perempuan dan santri lakilaki.

Pemisahan kelas berdasarkan jenis kelamin ini dalam dunia pendidikan moderen dikenal dengan Single Sex Education (SSE), yaitu pendidikan yang terpisah antara laki-laki dan perempuan, baik dalam lembaga yang terpisah maupun dalam lembaga yang sama. Kebalikan dari sistem SSE adalah sistem pembelajaran $C o$ Education (CE), dimana sistem ini tidak memisahkan antara lakilaki dan perempuan dalam proses pembelajarannya. Masing-masing dari model pembelajaran tersebut mempunyai keunggulan dan kekurangan berdasarkan penerapannya serta sistem kebijakan yang melingkupinya. Masing-masing juga menimbulkan pro dan kontra diantara para praktisi pendidikan. Perdebatan yang paling

${ }^{10}$ Sahal Mahfudh, Pesantren Mencari Makna, (Jakarta: Pustaka Ciganjur, 1999), hlm. 25. 
banyak dimunculkan adalah adu argumentasi antara keuntungan penerapan SSE dan $C E$ bagi masing-masing murid.

Pendidikan menengah di Amerika, saat pertama kali membuka sekolah bagi perempuan setelah satu setangah abad pasca perang revolusi, menawarkan pendidikan dengan model $C E$ untuk daerah barat dan SSE di daerah timur laut yang lebih makmur keadaannya. Namun demikian pada tahun 1900 an, 98\% sekolah menengah umum menggunakan model $C E$. Pada tahun 1960 an merupakan masa dimana banyak muncul sekolah menengah dengan model SSE. Hal ini tidak bertahan lama sejak diterbitkannya undang-undang tentang pendidikan Title IX legislation, sehingga pada tahun 1970-an banyak sekolah yang beralih kembali menjadi $C E$. Undang-undang tersebut berisi larangan diskriminasi jenis kelamin dan peningkatan sumberdaya manusia yang tidak merata. Namun hal ini tidak mematahkan semangat para penggerak SSE untuk tetap mempertahankan model ini. ${ }^{11}$

Perdebatan antara SSE dan $C E$ telah berlangsung lama. Masing-masing menunjukkan mana yang lebih baik bagi pendidikan, terutama untuk sekolah menengah. Namun, keberadaannya akhirakhir ini menjadi penting dengan asumsi untuk memajukan kesetaraan gender. Para peneliti di University of Michigan membandingkan lulusan sekolah menengah katolik SSE dengan lulusan sekolah menengah katolik sistem $C E$. Murid laki-laki dari $S S E$ mencetak prestasi yang lebih baik dalam membaca, menulis, dan matematika daripada murid laki-laki di sekolah $C E$. Sedangkan murid perempuan di sekolah SSE mencetak prestasi yang lebih baik dalam hal sains dan membaca dibandingkan anak perempuan di sekolah $C E$. Bahkan, para peneliti menemukan bahwa murid di sekolah SSE tidak hanya prestasi akademik yang unggul, tetapi juga memiliki aspirasi pendidikan yang lebih tinggi, lebih percaya diri dalam kemampuan mereka, dan sikap yang lebih positif terhadap akademisi, daripada murid di sekolah $C E$. Murid perempuan di SSE kurang memiliki gagasan stereotype tentang apa yang perempuan bisa dan tidak bisa lakukan. ${ }^{12}$ Perempuan yang belajar

11 Fred A. Mael, "Single-Sex and Coeducational Schooling: Relationships to Socioemotional and Academic Development", Review of Educational Research, (Amerika: American Educational Research Association, 1998), hlm. 102.

12 Valerie Lee and Anthony Bryk, "Effects of Single-Sex Secondary Schools on Student Achievement and Attitudes", Journal of Educational Psychology, Volume 78, (1986), hlm. 381-395. 
di $S S E$ mengalami sistuasi belajar yang nyaman karena mereka dapat belajar tanpa ada persaingan dan gangguan dari murid lakilaki. Mereka juga tidak harus dipusingkan dengan persaingan merebut perhatian dari para guru ${ }^{13}$ dan tidak mengalami gangguan konsentrasi belajar akibat ketertarikan seksual dengan lawan jenis.

Bila dibandingkan, keberadaan sekolah dengan model $C E$ lebih banyak dari pada model SSE. Hal ini mungkin dipengaruhi oleh anggapan bahwa model $C E$ lebih alami, karena dalam kehidupan ini hampir semua sisinya diwarnai keberadaan perempuan dan laki-laki secara bersama-sama. Single sex education (SSE) lebih sering diterapkan bagi murid perempuan, meskipun ada juga $S S E$ untuk murid laki-laki. Namun dalam lingkup pesantren, SSE disediakan baik untuk laki-laki maupun untuk perempuan dengan alasan utama berdasarkan ajaran Islam, yaitu adanya larangan lakilaki dan perempuan berada dalam satu ruangan. Model pendidikan SSE maupun $C E$, selalu menuai perdebatan untuk menunjukkan model mana yang lebih baik. Sebagai contoh gambaran perdebatan tersebut dapat ditemukan dalam laporan penelitian yang dilakukan oleh Chattopadhay. ${ }^{14}$ Dalam penelitiannya ini dilaporkan tentang usaha masyarakat untuk mewujudkan pendidikan yang setara gender, terutama bagi perempuan, karena semua anak tanpa membedakan jenis kelamin berhak mendapatkan pendidikan yang layak. Disisi lain penelitian ini dilakukan sebagai tanggapan terhadap kebutuhan informasi yang diungkapkan oleh tim-tim kebijakan pendidikan di negara-negara Asia di mana anak perempuan menghadapi lebih banyak hambatan daripada anak laki-laki dalam akses pendidikan. Eksplorasi tersebut dilakukan untuk melihat akses anak perempuan terhadap pendidikan serta kualitas dan relevansi pendidikan tersebut dalam kehidupan. Tim penentu kebijakan pendidikan menggunakan kerangka kerja penelitian ini untuk menentukan model yang terbaik untuk pendidikan, terutama bagi anak perempuan.

Bila dilihat lebih mendalam, SSE selain memiliki keuntungan juga menyebabkan kerugian bagi murid perempuan. Hal ini dapat dilihat dari sudut pandang yang mendukung dan menentang model $S S E$. Beberapa hal yang mendukung model pembelajaran SSE ini

${ }^{13}$ Stephanie Garret, Gender: Society Now, (London: Tavistock Publication Ltd, 1987), hlm. 85.

${ }^{14}$ Chattopadhay, Single-Sex Schools for Girls and Gender Equality in Education-Advocacy Brief), (Bangkok: Unesco Bangkok, 2007). 
-terutama bagi anak-anak di Asia sebagaimana hasil penelitian Chattopadhay tersebut-antara lain dapat dilihat dari:

1. Agama dan budaya. Dalam konteks agama dan budaya tertentu, orang tua yang memiliki anak perempuan lebih memilih model pendidikan yang memisahkan murid laki-laki dan perempuan. Hal ini dilakukan berdasarkan ajaran agama yang mereka anut atau budaya masyarakat di sekitar mereka. Hal ini bisa dijadikan salah satu alasan sering memberikan perlakuan yang menyudutkan posisi murid perempuan. Misalnya, terdapat guru yang memulangkan muridnya dengan cara memberikan kuis di akhir pelajaran. Hal ini secara tidak sengaja menyebabkan perempuan tidak berani menjawab kuis karena malu apabila salah dan menyebabkan murid laki-laki menjadi lebih agresif. Desain ruang kelas juga mengarah pada bias gender. Banyak sekolah menghias kelasnya dengan memajang gambar atau photo pahlawan atau tokoh laki-laki daripada tokoh perempuan. Perlakuan guru terhadap murid juga berbeda. Biasanya murid perempuan diminta untuk membantu membersihkan ruang kelas, sementara murid lakilaki diperbolehkan untuk bermain. Bahkan murid laki-laki lebih diperhatikan daripada murid perempuan. ${ }^{15}$ Dalam SSE, ditemukan bukti bahwa murid perempuan dapat belajar tanpa adanya gangguan ejekan dari murid laki-laki serta dapat lebih bebas untuk berekspresi. Jika mereka diberi kesempatan untuk mempelajari hal yang sama dengan murid laki-laki, maka hasilnya akan sama dengan kemampuan murid laki-laki, bahkan mungkin lebih baik.

2. Tantangan masa pubertas. Murid laki-laki dan perempuan yang menginjak dewasa sangat sensitif untuk terlihat kurang menarik di depan lawan jenisnya, jika mereka berada dalam satu kelas. Hal ini dapat mempengaruhi konsentrasi dan potensi akademiknya. SSE dapat membantu untuk lebih fokus dalam belajar dan meningkatkan prestasi akademik mereka.

3. Kekerasan. Pelecehan seksual dan kekerasan berdasarkan gender dapat terjadi dimana saja, meskipun di sekolah yang menerapkan SSE. Namun biasanya hal ini banyak terjadi di sekolah yang menerapkan $C E$. Selain hal tersebut, dapat juga terjadi intimidasi atau mempermalukan orang lain di muka umum. Sekolah $C E$ biasanya tidak menyediakan toilet secara

${ }^{15}$ Chattopadhay, Single-Sex Schools ..., hlm. 80. 
terpisah jenis kelamin. Hal ini akan mengganggu kenyamanan dan menimbulkan resiko tinggi bagi perempuan.

4. Harga diri. Para murid perempuan lebih dapat mengembangkan potensi diri dan kemampuan akademis mereka apabila mereka berada dalam kelas SSE. Mereka dapat mengembangkan potensi tersebut tanpa merasa malu terhadap lawan jenisnya.

Sedangkan dari pihak yang kurang setuju dengan sekolah model SSE menyatakan keberatannya dengan alasan sebagai berikut:

1. Biaya. Jika dalam suatu lembaga sudah mempunyai kelas dengan sistem co-education, maka untuk mewujudkan single sex education membutuhkan dana untuk pembangunan gedung baru dan pemeliharaannya. Lembaga juga harus menyediakan manajemen pengelolaan dengan kualitas yang sama dengan kelas terdahulu, harus menyediakan lebih banyak guru dan staf yang terlatih.

2. Kualitas guru. Kurangnya guru yang berkualitas di SSE dapat secara drastis mengurangi kualitas pendidikan murid perempuan. Untuk kasus di pesantren, sangat kesulitan untuk mencari guru perempuan yang mempunyai sumber daya manusia yang sama dengan guru laki-laki, selain disebabkan pula lebih cepatnya masa belajar perempuan dikarenakan lebh cepat untuk menikah. Kekurangan guru yang berkualitas ini juga disebabkan oleh rendahnya jumlah perempuan yang berpendidikan tinggi.

3. Ketrampilan sosial. SSE dianggap sebagai sistem pendidikan yang tidak wajar karena mengisolasi perempuan dari anak laki-laki. Dalam sistem $C E$ yang dikelola dengan baik dapat menciptakan lingkungan pendidikan yang baik dimana murid laki-laki dan perempuan belajar untuk menghormati dan menghargai ide-ide masing-masing. Mereka belajar untuk mendengarkan dan berkomunikasi satu sama lain. Mengisolasi perempuan dan anak laki-laki dalam SSE dianggap sebagai penghalang bagi mereka untuk mengembangkan interpersonal yang efektif sebagai sebuah keterampilan yang mereka butuhkan untuk hidup sebagai orang dewasa dalam masyarakat mereka kelak.

4. Bias gender sistemik. SSE dapat menyebabkan anak laki-laki dan perempuan tidak saling menyaksikan ide-ide, bakat dan 
keterampilan dari jenis kelamin lain. Mereka menjadi kaku terhadap jenis kelamin lain. Hal ini dapat memperkuat adanya bias gender dalam masyarakat. Selain itu, ada beberapa berpendapat yang mengatakan bahwa menciptakan sekolahsekolah khusus untuk anak perempuan akan menunjukkan bahwa anak perempuan memiliki masalah dan membutuhkan perhatian khusus. Hal ini justru dapat menyebabkan anak perempuan menjadi berpikir kurang positif pada diri mereka sendiri.

5. Terbatasnya akses jaringan dan informasi. SSE tidak memfasilitasi anak-anak untuk menjalin persahabatan dengan anak laki-laki yang kemudian dapat memberikan hubungan yang berguna untuk jaringan dunia publik yang biasanya didominasi laki-laki.

6. Budaya maskulinitas. SSE secara langsung memisahkan pergaulan antara murid laki-laki dan perempuan. Hal ini menyebabkan masalah yang buruk baik pada murid laki-laki maupun murid perempuan. Murid laki-laki akan semakin merasa bangga dengan kejantanannya dengan menindas murid laki-laki lain yang lebih lemah dan akan menciptakan rasa keterasingan terhadap perempuan dengan menganggap perempuan sebagai makhluk kedua setelah laki-laki. Hal ini pada gilirannya dapat memperburuk hubungan antara anak laki-laki dan anak perempuan dalam konteks sosial di luar sekolah.

7. Menghindari perilaku buruk. SSE untuk murid perempuan didirikan sebagai upaya menciptakan rasa aman dan nyaman dalam masa belajar bagi anak perempuan. Namun hal ini belum maksimal jika keamanan dan kenyamanan itu hanya terbatas di lingkungan sekolah. Maka banyak sistem yang harus dibenahi jika ingin menciptakan lingkungan yang aman dan nyaman terutama bagi perempuan. Jangan sampai usaha membuat sekolah dengan sistem SSE justru akan menimbulkan perilaku yang buruk terhadap perempuan di tempat yang lain.

Dari paparan tentang contoh penerapan single-sex education bagi murid perempuan tersebut dapat dilihat bahwa sebenarnya baik single-sex education, co-education maupun mix-education, semua memiliki potensi untuk memberikan rasa aman dan nyaman saat belajar bagi murid perempuan dan laki-laki. Semuanya tergan- 
tung bagaimana cara pengelolaan dan kurikulum yang diterapkan di masing-masing sekolah tersebut, serta upaya agar terdapat standar yang sama antara murid perempuan dan murid laki-laki.

\section{Realitas Pendidikan Perempuan di Pesantren}

Mayoritas pondok pesantren di Indonesia, terutama Jawa, menyelenggarakan pendidikan dengan sistem terpisah antara santri perempuan dan santri laki-laki, dalam proses pembelajaran maupun secara administrasi. Sebagian pesantren memberikan perlakuan yang sama di antara mereka, namun ada juga yang terkesan masih membatasi ruang gerak santri perempuan. Perlakuan sama yang biasa diberikan kepada santri adalah tentang jam belajar yang sama, materi pelajaran yang sama, pengajar yang sama, aktivitas pembelajaran yang sama serta aturan yang sama. Beberapa pesantren yang menyatakan lembaganya telah memberikan kesempatan, akses, partisipasi dan kontrol yang sama antara santri perempuan dan santri laki-laki, antara lain seperti Pondok Pesantren Abu Huroiroh Jombang, Pondok Pesantren Mataliul Anwar Lamongan dan Pondok Pesantren Nurul Hidayah Garut.

Pondok Pesantren Abu Huroiroh ${ }^{16}$ Jombang terletak di Dusun Juwet Desa Glagahan Kecamatan Perak Kabupaten Jombang, yang berbatasan langsung dengan Kabupaten Nganjuk. Pesantren ini didirikan tahun 1972 dengan tampilan yang masih sangat sederhana dan sistem pembelajaran tradisional. Sejalan dengan perkembangan masyarakat dan kebutuhan mereka terhadap pendidikan, akhirnya saat ini PP Abu Huroiroh memiliki lembaga pendidikan Madrasah Ibtidaiyah, Madrasah Tsanawiyah, SMA dan SMK dengan jumlah siswa keseluruhan sekitar 1.250 dan tenaga pengajar 87 orang yang terdiri dari 53 guru perempuan dan 34 guru laki-laki. Pengasuh pondok ini mengaku tidak mengenal diskriminasi jenis kelamin dalam pendidikan. Hal ini dibuktikan dengan adanya perlakuan yang sama bagi para santri terutama dalam bidang tata tertib, dimana biasanya secara umum banyak pesantren yang memberlakukan aturan yang lebih ketat bagi santri perempuan. Di pondok ini santri perempuan mendapatkan kesempatan yang sama dalam berbagai kegiatan, baik dalam kepanitiaan

${ }^{16}$ Disarikan dari tulisan Mu'minin, "PP Abu Huroiroh, Jombang, Bangun Kesetaraan di Dunia Pendidikan", Swara Rahima, No. 33 Th. X, Desember 2010, hlm. 35-37. 
maupun beraktivitas. Ruang belajar juga tidak dipisahkan, begitu juga guru laki-laki dan guru perempuan diperkenankan mengajar mereka sesuai dengan kapasitas dan kompetensinya. Hal ini sangat didukung oleh pimpinan pondok, yaitu KH. Maslul Ustad, dengan mengatakan "Kesetaraan laki-laki dan perempuan merupakan bagian tidak terpisahkan dari prinsip asasi tentang musawah wa al'adalah (kesetaraan dan keadilan) dalam maqasid asy-syari'ah (tujuan syariah)".

Ucapan kiai ini tidak hanya sekedar ucapan namun dibuktikan dengan adanya kerjasama yang baik dan egaliter antara kiai dengan nyai. Bu Nyai mempunyai jadwal yang padat pada pengajian rutin warga Muslimat NU Kecamatan Perak selain memberikan pengajian bagi para santri. Selain itu kiai juga memberikan kesempatan bagi para guru untuk memahami kesetaraan antara perempuan dan laki-laki dengan mengadakan kegiatan peningkatan proses pembelajaran yang bekerjasama dengan Yayasan Rahima dengan tema "Menumbuhkan Sensitivitas Gender Melalui Pembelajaran Inklusif Gender" pada tahun 2009. Pembelajaran Inklusif Gender merupakan bentuk pembelajaran yang dimaksudkan untuk mengatasi masalah kesenjangan dalam mencapai pendidikan yang tersegregasi secara jenis kelamin. Hal tersebut menyangkut materi, bahan ajar, strategi pembelajaran serta bahasa yang menghargai segala aspek pengalaman hidup baik laki-laki maupun perempuan secara setara. Dengan demikian diharapkan para guru dapat menumbuhkan motivasi belajar para santri dengan menghargai pengetahuan dan pengalaman mereka sebagai laki-laki dan perempuan.

Berikutnya adalah Pondok Pesantren Matholiul Anwar ${ }^{17}$ atau lebih dikenal dengan Pondok Mawar, yang terletak di Dusun Simo Desa Sungailebak Kecamatan Karanggeneng Kabupaten Lamongan. Pondok ini didirikan oleh KH. Abdul Wahab pada 18 Jnauari 1914. Pada mulanya pondok ini hanya berbentuk kegiatan pengajian yang bertempat di sebuah rumah milik keluarga $\mathrm{KH}$. Abdul Wahab, namun sekarang sudah memiliki lembaga pendidikan mulai TK, MI, MTs, MA, SMP NU, SMK NU dan bahkan Universitas Islam Darul Ulum (UNISDA). Jumlah semua santri mencapai 3.500 dengan santri mukim 700 orang. Tanpa disengaja,

17 Disarikan dari tulisan Anis Suadah, "Pondok Pesantren MAWAR (Matholiul Anwar) Lamongan, Pesantren Pejuang Kesetaraan Gender", Swara Rahima, No. 36 Th. XI, September 2011, hlm. 40-41. 
pondok ini lebih banyak menerima santri perempuan. Uniknya, salah satu visi misi pondok adalah sebagai sebuah ikhtiar untuk menghapuskan ketidakadilan yang diakibatkan oleh ketimpangan relasi gender. Ibu Nyai Khotim, salah satu nyai pada pondok tersebut mengatakan, "Kaum perempuan terlalu lama didiskriminasikan, oleh karenanya perlu ada lembaga khusus untuk pemberdayaan perempuan".

Pondok Mawar menghapus stigma bahwa perempuan hanya bisa masak, macak, manak, namun perempuan harus bisa tampil di ruang publik karena pada dasarnya perempuan dan laki-laki itu sama saja. Secara bersama-sama semua santri wajib mengikuti kegiatan baik formal maupun ekstrakurikuler, seperti Madrasah Diniyah dan Pengajian Kitab Kuning. Bahkan santri putri dianjurkan untuk mengikuti kegiatan IPPNU dan Fatayat NU. Selain itu juga ada kegiatan Simaan al-Quran, Barjanji serta Lembaga Kegiatan Ilmiah Remaja dan Kesehatan Reproduksi Remaja.

Hal yang hampir sama juga terjadi di Pondok Pesantren Nurul Hidayah $^{18}$ terletak di Desa Pamalayan Kecamatan Cikelet Kabupaten Garut. Pesantren ini didirikan tahun 1963 oleh KH. Ijudin Nawawi. Pesantren yang masih memegang teguh pola pikir konservatif ini, belakangan diwarnai dengan pendidikan formal. Pada tahun 2005 pesantren ini mulai mendirikan SMP dan SMA dengan system yang integral. Seluruh unsur pengelola pesantren merombak pola pikir yang dahulu menempatkan perempuan sebagai kelompok yang terpinggirkan dalam pendidikan. Kini mereka semakin membuka kesempatan bagi perempuan untuk menuntut ilmu sebagaimana laki-laki.

Hal unik yang dimiliki pesantren inilah adanya istilah RUBU yang merupakan singkatan dari riyāọotunnafsi, ulüman, bāligan ukhwatan. Riyādatunnafsi adalah ajaran mengelola jiwa dan raga agar seimbang. Ulüman adalah berilmu, sebagai syarat utama bagi pendidik yang akan memberi bekal para santri agar jadi orang yang berilmu. Bāligan adalah panggilan jihad untuk menyampaikan dan mengamalkan ilmu yang telah diperoleh para santri selama mondok. Sedangkan ukhwatan adalah prinsip kerjasama dan persaudaraan. Selain itu istilah rubu' ini juga dikaitkan dengan ilmu perbintangan atau ilmu falak, dimana Kiai Ijudin

${ }^{18}$ Disarikan dari tulisan Nuraisyah Hidayah, "PP. Nurul Hidayah: Beri Kesempatan Luas untuk Perempuan”, Swara Rahima, No. 29 Th. IX, Desember 2009, hlm. 33-34. 
mengajarkan ilmu tersebut kepada seluruh santrinya baik laki-laki maupun perempuan. Pesantren ini juga mengajarkan ilmu qiro'at al-Quran tanpa diskriminasi, sehingga di pesantren ini kebanyakan santri perempuan ahli di bidang ilmu falak serta qiro'at. Sebab itulah, maka masyarakat semakin terbuka mengenai relasi sosial antara perempuan dan laki-laki. Hal ini pula yang memberi inisiatif mengubah corak pesantren sehingga lebih memberi ruang yang setara bagi laki-laki dan perempuan.

Jika ketiga pesantren tersebut di atas adalah contoh pesantren yang telah memberikan kesempatan dan perlakuan yang sama terhadap santri laki-laki dan perempuannya, maka berikut ini adalah beberapa pesantren yang di dalamnya masih terdapat pembedaan perlakuan terhadap santri perempuannya. Sebagai contoh, diantaranya adalah Pondok Pesantren Salafiyah Syafi'iyah Sukorejo Situbondo ${ }^{19}$, Pesantren al-Munawwir dan Pesantren Ali Maksum Krapyak Yogyakarta ${ }^{20}$ dan Pondok Pesantren Darul Huda Mayak Tonatan Ponorogo. ${ }^{21}$ Ketiga pesantren tersebut mempunyai lembaga pendidikan untuk laki-laki dan perempuan yang proses pembelajarannya dilaksanakan secara terpisah dan terdapat pembedaan perlakuan.

Pondok Pesantren Salafiyah Syafi'iyah terletak di Dusun Sukorejo Desa Sumberejo Kecamatan Banyuputih yang termasuk eks Karesidenan Asembagus Kabupaten Situbondo. Pondok ini didirikan oleh Kiai Syamsul Arifin pada tahun 1914, yang sekarang telah berkembang pesat dan mempunyai lembaga pendidikan seperti RA, MI, SD, MTs, SMP, SMA, SMK, dan Institut Agama Islam Ibrahimy. Selain itu pesantren ini juga memiliki Ma'had Aly yang merupakan lembaga pendidikan tingkat magister untuk ilmu-ilmu pesantren. ${ }^{22}$

Pembedaan perlakuan di pesantren ini salah satunya terletak pada adanya diskriminasi baik itu dalam hal akses, partisipasi dan kontrol bagi perempuan. Meskipun tampaknya santri perempuan di pesantren ini mendapatkan kesempatan yang sama, namun terdapat beberapa hal yang berbeda yang kemudian hal tersebut

${ }^{19}$ Lebih lanjut lihat Mufidah, Gender di Pesantren Salaf, Why Not?, (Malang: UIN Maliki Press, 2010).

20 Lebih lanjut lihat Ema Marhumah, Konstruksi Sosial Gender di Pesantren, (Yogyakarta: LKiS, 2011).

${ }^{21}$ Pesantren ini menjadi subyek penelitian disertasi penulis yang saat tulisan ini dibuat masih dalam proses penyelesaian.

${ }^{22}$ Mufidah, Gender di ..., hlm. 20. 
menjadi hambatan bagi santri perempuan. Hambatan pertama adalah hambatan secara psikologis. Keadaan ini lebih disebabkan oleh penilaian diri mereka secara psikologis sebagai pihak yang lemah dan inferior. Pada saat diskusi berlangsung, mereka merasa bahwa pendapat yang mereka utarakan kurang berbobot atau bahkan merasa minder karena sering mendapatkan perlakuan yang kurang menyenangkan, seperti ditertawakan oleh teman laki-laki. ${ }^{23}$

Hambatan kedua berkaitan dengan jalur akses terhadap guru privat untuk belajar secara individual dalam upaya mengatasi ketertinggalan materi kuliah, karena musyrif yang berfungsi memberikan bimbingan belajar semuanya laki-laki. Selain itu, kendati materi yang diberikan sama, namun penggunaan fasilitas perpustakaan bagi santri perempuan sangat terbatas. Mereka hanya boleh ke perpustakaan bila terdapat lebih dari 3 orang, itupun hanya pada jam-jam tertentu dan tidak bebas sebagaimana santri laki-laki. Hambatan ketiga adalah terbatasnya akses untuk mengikuti kegiatan di luar pesantren bagi santri perempuan, sehingga ide dan informasi mengenai masalah sosial di luar pesantren didapatkan dari pihak kedua atau tidak secara langsung dari sumber asalnya. Maka tidaklah heran jika prestasi belajar santri laki-laki lebih baik dibandingkan santri perempuan, termasuk jumlah santri yang bertahan untuk belajar di Ma'had Aly tersebut. Hal ini adalah akibat dari sistem pembelajaran yang masih bias gender. ${ }^{24}$

Di sisi lain jumlah santri perempuan lebih banyak daripada santri laki-laki, namun jumlah guru perempuan lebih sedikit daripada guru laki-laki. ${ }^{25}$ Guru laki-laki boleh mengajar semua santri,

${ }^{23}$ Hal ini terjadi di lembaga Ma'had Aly, dimana antara santri laki-laki dan santri perempuan kelasnya disatukan, dengan alasan mahasiswanya hanya sedikit. Mufidah, Gender di ..., hlm. 238.

${ }^{24}$ Mufidah, Gender di ..., hlm. 239

25 Jumlah murid di PP Salafiyah Syafi'iyah Sukorejo Situbondo mulai tingkatan Roudlotul Athfal hingga Madrasah Aliyah adalah 5.654 anak, yang terdiri dari 2.784 laki-laki dan 2.861 perempuan. Secara administrasi, manajemen sekolah di madrasah tsanawiyah sudah terpisah, namun dalam pengambilan keputusan yang dipandang penting masih harus dikoordinasikan dengan Kepala MTs putra. Sedangkan administrasi di SMP masih menyatu. Jika diadakan rapat dan pengambilan keputusan selalu didominasi oleh lakilaki dan dianggap bahwa permasalahan antara santri perempuan dan santri laki-laki adalah sama, padahal dalam kenyataannya sangat berbeda. Ibid., hlm. 227-229. Kejadian seperti ini juga terjadi pada pondok Ali Maksum, Al-Munawwir dan Darul Huda. Lihat Ema Marhumah, Konstruksi Sosial Gender di Pesantren, hlm. 43-44 dan 99. 
meskipun dengan persyaratan hanya guru laki-laki yang sudah menikah yang boleh mengajar santri perempuan. Namun hal ini tidak berlaku sebaliknya, bahwa guru perempuan hanya boleh mengajar santri perempuan. Hal demikian ini banyak terjadi di pesantren, karena menganggap bahwa jika guru perempuan mengajar santri laki-laki akan banyak menimbulkan madarat. ${ }^{26}$

Kegiatan pembelajaran yang hampir sama juga terjadi di Pesantren al-Munawwir dan Pesantren Ali Maksum. Kedua pesantren ini adalah dua pesantren besar yang terletak dalam satu komplek di Dusun Krapyak Kecamatan Sewon Kabupaten Bantul Yogyakarta. Pesantren al-Munawwir didirikan terlebih dahulu oleh KH. Munawwir pada 15 November 1910. Sepeninggal KH. Munawwir, pesantren ini diteruskan oleh menantunya, KH. Ali Maksum. Namun akhirnya pada tahun 1990 pesantren terpisah menjadi Pesantren al-Munawwir dan Pesantren Ali Maksum, dimana Pesantren al-Munawwir lebih bernuansa salaf, sedangkan Pesantren Ali Maksum bernuansa modern. ${ }^{27}$

Pembedaan perlakuan di kedua pesantren tersebut salah satunya terletak pada kebiasaan pengasuh yang mengirimkan santri laki-laki senior untuk mengisi pengajian di daerah sekitar. Santri yang dikirim ke daerah tersebut umumnya didominasi oleh laki-laki karena dirasa lebih aman daripada mengirim santri perempuan, disamping memang selama ini banyak masyarakat yang memang meminta penceramah laki-laki, kecuali untuk pengajian khusus ibu-ibu atau anak-anak. Hal tersebut menunjukkan bahwa domestifikasi peran perempuan dalam kegiatan sosial religious. Peran santri perempuan dianggap hanya berhubungan dengan aktivitas yang lebih sederhana, bersifat domestik dan lebih mementingkan unsur keperempuanan. Kegiatan yang bersifat massal dan yang lebih bergengsi dianggap sebagai wilayah laki-laki.

Pembedaan lain adalah tentang lokasi sekolah, dimana lokasi sekolah untuk santri laki-laki lebih dekat dengan kamar masingmasing, sehingga tidak membutuhkan tenaga ekstra untuk menuju kelas. Sedangkan lokasi sekolah perempuan jaraknya agak jauh dan harus melintasi jalan raya. Peraturan yang diterapkannya pun berbeda. Antara lain bahwa perempuan hanya boleh keluar pesantren pada hari Jum'at saja dan hanya boleh berbelanja di kantin

\footnotetext{
${ }^{26}$ Mufidah, Gender di ..., hlm. 231.

${ }^{27}$ Ema Marhumah, Konstruksi Sosial Gender di Pesantren, hlm. 42-48.
} 
yang ada di dalam pesantren. Namun tidak demikian bagi santri laki-laki. Spesifikasi peraturan yang ada ini memperkuat perbedaan gender yang justru melanggengkan stereotype antara santri laki-laki dan santri perempuan dalam pengembangan identitas mereka. Perbedaan ini pada akhirnya akan mendukung ketidaksetaraan akses dan kontrol terhadap informasi dan ekspresi kejiwaan mereka masing-masing. ${ }^{28}$

Sekolah di kedua pesantren ini juga memiliki peran yang dominan dalam terjadinya diskriminasi terhadap guru laki-laki dan guru perempuan. Kedua jenis kelamin tersebut boleh mengajar di sekolah, akan tetapi guru perempuan tidak pada semua mata pelajaran dapat mengajar santri laki-laki. Perempuan hanya dapat mengajar laki-laki pada mata pelajaran biologi dan matematika. Itupun dengan alasan sekolah ini tidak mempunyai guru biologi dan matematika laki-laki. Dalam pengakuannya, kepala sekolah di sekolah ini mengatakan bahwa guru perempuan akan mendatangkan maḍarat bila mengajar santri laki-laki karena berpotensi menimbulkan syahwat, namun tidak demikian jika guru laki-laki mengajar santri perempuan. Sedangkan di lembaga madrasah salafiyah khususnya di Pesantren al-Munawwir, justru tidak ada satupun guru perempuannya. ${ }^{29}$ Sehingga hal ini menegaskan bahwa santri laki-laki tidak akan mempunyai guru perempuan yang dapat dijadikan teladan dalam kehidupan mereka, terlebih ditambah dengan banyaknya materi pelajaran yang sarat dengan nuansa bias gender dan diberikan secara berulang-ulang. ${ }^{30}$

Bila dilihat dari sisi sejarah, sebenarnya di ketiga pesantren tersebut sudah pernah mengenal kajian tentang kesetaraan antara laki-laki dan perempuan. Maka sangat disayangkan jika masih terdapat diskriminasi kesempatan dalam masalah pendidikan. Hal ini sangat berbeda dengan Pondok Pesantren Darul Huda, yang hingga saat ini belum pernah mendapatkan atau bersinggungan dengan hal-hal yang menyangkut permasalahan kesetaraan gender. Pesantren yang terletak di Dusun Mayak Desa Tonatan Ponorogo ini didirikan oleh KH. Hasyim Sholeh pada tahun 1968. Pondok ini mengalami peningkatan jumlah santri yang sangat signifikan justru setelah meninggalnya sang pendiri, dimana selanjutnya kepemimpinan pondok dipegang oleh putra sulungnya, yaitu $\mathrm{KH}$.

\footnotetext{
${ }^{28}$ Ema Marhumah, Konstruksi Sosial ..., hlm. 60, 75

${ }^{29}$ Ema Marhumah, Konstruksi Sosial ..., hlm. 63-64.

${ }^{30}$ Ema Marhumah, Konstruksi Sosial ..., hlm. 135.
} 
Abdus Sami’ hingga sekarang. Sebagaimana lazimnya pesantren, pondok ini menekankan materinya pada kajian kitab kuning melalui Madrasah Diniyah Miftahul Huda dan pengajian wetonan. Namun disisi lain pondok ini juga mendirikan MTs dan MA yang setiap tahun jumlah siswanya selalu meningkat.

Mungkin menjadi suatu kewajaran jika di pondok ini masih terdapat pembedaan perlakuan terhadap santri perempuan, mengingat bahwa di pondok ini belum pernah mendapatkan kajian tentang kesetaraan gender. Secara sepintas memang semua santri mendapatkan perlakuan yang sama. Namun ada beberapa hal yang berbeda. Jumlah santri didominasi oleh santri perempuan, akan tetapi jumlah guru perempuan sangat terbatas. Sehingga hal ini menyebabkan guru laki-laki boleh mengajar santri perempuan dan sekaligus santri laki-laki, namun guru perempuan tidak diperkenankan mengajar santri laki-laki dengan alasan akan menimbulkan madarat. Selain itu terdapat pula materi pelajaran yang tidak diberikan kepada santri perempuan namun diberikan kepada santri laki-laki ataupun sebaliknya. Jika santri laki-laki mendapatkan pelajaran Ilmu Falak, maka tidak demikian dengan santri perempuan. Alasan yang dikemukakan adalah adanya keilmuan yang dianggap lebih penting untuk dipelajari bagi perempuan yaitu kita Risālatul Mahị̣, suatu kitab yang membahas tentang menstruasi dan permasalahannya. Perbedaan semakin tampak ketika santri laki-laki mendapatkan pelajaran juga tentang kitab ini dalam bentuk diklat, namun tidak demikian bagi santri perempuan.

Kebijakan pemberlakuan tata tertib juga ada yang berbeda antara santri laki-laki dan santri perempuan, antara lain waktu ijin keluar pesantren untuk laki-laki lebih longgar dan lebih lama. Mereka diijinkan keluar pesantren hari apa saja asalkan tidak meninggalkan kegiatan rutin. Sedangkan untuk perempuan ijinnya lebih sulit dan waktunya terbatas serta tidak boleh keluar sendirian. Mereka hanya boleh keluar pesantren sebulan sekali. Dalam hal akses sumber belajar juga terdapat perbedaan dimana santri perempuan mendapatkan waktu yang sangat terbatas untuk mengunjungi perpustakaan, yaitu hanya pada jam istirahat. Bahkan perpustakaan santri perempuan ruangannya lebih kecil jika dibandingkan dengan perpustakaan santri laki-laki dan terletak di lantai empat. Namun demikian ada hal lain yang perlu dibanggakan bagi santri perempuan, dimana meskipun mereka mengalami pembedaan di beberapa hal, tetapi tingkat kreatifitas dan 
prestasi mereka lebih baik jika dibandingkan dengan santri lakilaki. ${ }^{31}$

\section{E. Penutup}

Rasulullah saw., tidak membedakan antara perempuan dan laki-laki dalam memperoleh kesempatan untuk mendapatkan pendidikan. Islam datang untuk menyamakan derajat diantara mereka tanpa memandang jenis kelamin dan strata sosial. Islam memberikan ajaran kepada pengikutnya untuk belajar tanpa mengenal batasan tempat, waktu maupun usia, baik itu perempuan maupun laki-laki. Nabi Muhammad datang untuk merubah budaya jahiliyah dengan cara memberikan kesempatan yang sama bagi perempuan untuk mendapatkan pendidikan.

Meskipun dahulu sistem pendidikan di Indonesia juga sempat menomorduakan kepentingan perempuan, namun lambat laun hal itu mulai terkikis. Masyarakat Indonesia, demikian juga warga pesantren, mulai merasakan bahwa pendidikan juga sangat dibutuhkan dan penting bagi perempuan. Namun demikian sebagian besar pesantren di Indonesia menerapkan pendidikan dengan sistem segregasi gender, yaitu terpisah antara santri perempuan dan laki-laki. Pemisahan ini bukan tidak menimbulkan permasalahan, namun semuanya dilakukan dengan tujuan agar tidak terjadi hal-hal yang melanggar aturan agama. Akan sangat bijaksana jika pemisahan itu bukan berarti memberikan kesempatan yang berbeda diantara mereka. Penerapan single-sex education bagi murid perempuan tersebut dapat dilihat bahwa sebenarnya baik singlesex education, co-education maupun mix-education, semua memiliki potensi untuk memberikan rasa aman dan nyaman saat belajar bagi murid perempuan dan laki-laki. Semuanya tergantung bagaimana cara pengelolaan dan kurikulum yang diterapkan di masingmasing sekolah tersebut, serta upaya agar terdapat standar yang sama antara murid perempuan dan murid laki-laki. Sehingga meskipun pembelajaran dilakukan terpisah namun prestasi belajar yang dihasilkan akan memuaskan dan masing-masing menjadi generasi muda yang sesuai dengan harapan bangsanya.

${ }^{31}$ Hasil pengamatan awal yang penulis lakukan pada observasi penelitian disertasi di Pondok Pesantren Darul Huda Mayak Tonatan Ponorogo pada Desember 2011. Disertasi masih dalam proses penulisan. 


\section{Kepustakaan}

Asrohah, Hanun. 2001. Sejarah Pendidikan Islam, Jakarta: Logos.

Burhanuddin, Jajat (ed.). 2002. Ulama Perempuan Indonesia, Jakarta: Gramedia.

Bukhari. Shahih Bukhari. CD Hadis as-Syarif no. 6766.

Chattopadhay. 2007. Single-Sex Schools for Girls and Gender Equality in Education-Advocacy Brief, Bangkok: Unesco Bangkok.

Dhofier, Zamakhsyari. 1982. Tradisi Pesantren, Studi Tentang Pandangan Hidup Kiai, Jakarta: LP3ES.

Garret, Stephanie. 1987. Gender: Society Now, London: Tavistock Publication Ltd.

Hidayah, Nuraisyah. 2009 . "PP. Nurul Hidayah: Beri Kesempatan Luas untuk Perempuan", Swara Rahima, No. 29 Th. IX, Desember.

Jackson, Carolyn. "Can Single Sex Classes in Co-Educational Schools Enhance the Learning Experiences of Girls and/or Boys? An Exploration of Pupils' Perceptions," British Educational Research Journal vol. 28, No. 1 (Feb., 2002).

Lee, Valerie and Anthony Bryk. 1986. "Effects of Single-Sex Secondary Schools on Student Achievement and Attitudes", Journal of Educational Psychology, Volume 78.

Marhumah, Ema. 2011. Konstruksi Sosial Gender di Pesantren, Yogyakarta: LKiS.

Mael, Fred A.. 1998. "Single-Sex and Coeducational Schooling: Relationships to Socioemotional and Academic Development", Review of Educational Research, Amerika: American Educational Research Association.

Mahfudh, Sahal. 1999. Pesantren Mencari Makna, Jakarta: Pustaka Ciganjur.

Mawardi, Kholid. 2008. "Madrasah Banat: Potret Pendidikan Anak Perempuan NU Masa Kolonial Belanda", Jurnal Studi Gender dan Anak Yin Yang, Purwokerto: PSG STAIN Purwokerto. 
Mu'minin. 2010. "PP Abu Huroiroh, Jombang, Bangun Kesetaraan di Dunia Pendidikan", Swara Rahima, No. 33 Th. X, Desember.

Mufidah. 2010. Gender di Pesantren Salaf, Why Not?, Malang: UIN Maliki Press.

Roded, Ruth. 1995. Kembang Peradaban, Bandung: Mizan.

Suadah, Anis. September 2011. "Pondok Pesantren MAWAR (Matholiul Anwar) Lamongan, Pesantren Pejuang Kesetaraan Gender”. Swara Rahima. No. 36 Th. XI.

Yunus, Mahmud. 1990. Sejarah Pendidikan Islam, Jakarta: PT. Hidakarya Agung.

Zakiyah, Nurul. 2002. "Keterkaitan Pendidikan Formal Perempuan dan Dunia Pembangunan", Jurnal Perempuan, Vol. 23, Jakarta: Yayasan Jurnal Perempuan. 
